\title{
Animal models of osteogenesis imperfecta: applications in clinical research
}

This article was published in the following Dove Press journal:

Orthopedic Research and Reviews

27 September 2016

Number of times this article has been viewed

\author{
Tanya A Enderli \\ Stephanie R Burtch \\ Jara $N$ Templet \\ Alessandra Carriero \\ Department of Biomedical \\ Engineering, Florida Institute of \\ Technology, Melbourne, FL, USA
}

Correspondence: Alessandra Carriero Department of Biomedical Engineering, Florida Institute of Technology, I50 West University Boulevard, Melbourne, FL 3290I, USA

Tel + I 32I 6748494

Email acarriero@fit.edu

\begin{abstract}
Osteogenesis imperfecta (OI), commonly known as brittle bone disease, is a genetic disease characterized by extreme bone fragility and consequent skeletal deformities. This connective tissue disorder is caused by mutations in the quality and quantity of the collagen that in turn affect the overall mechanical integrity of the bone, increasing its vulnerability to fracture. Animal models of the disease have played a critical role in the understanding of the pathology and causes of $\mathrm{OI}$ and in the investigation of a broad range of clinical therapies for the disease. Currently, at least 20 animal models have been officially recognized to represent the phenotype and biochemistry of the 17 different types of $\mathrm{OI}$ in humans. These include mice, dogs, and fish. Here, we describe each of the animal models and the type of OI they represent, and present their application in clinical research for treatments of OI, such as drug therapies (ie, bisphosphonates and sclerostin) and mechanical (ie, vibrational) loading. In the future, different dosages and lengths of treatment need to be further investigated on different animal models of OI using potentially promising treatments, such as cellular and chaperone therapies. A combination of therapies may also offer a viable treatment regime to improve bone quality and reduce fragility in animals before being introduced into clinical trials for OI patients.
\end{abstract}

Keywords: OI, brittle bone, clinical research, mouse, dog, zebrafish

\section{Introduction}

Osteogenesis imperfecta (OI), commonly known as brittle bone disease, is a genetic disorder characterized by extreme bone fragility, even if only exposed to mild trauma. The earliest known case of OI to occur in a human was determined by Peter Gray in 1969 in his analysis of bones of an approximately 3,000-year-old mummified infant. ${ }^{1}$ However, it was only in 1788 that OI became recognized as a human disease, when it was given its first true pathological description. ${ }^{1}$ By 1979 , researchers had classified OI into four different types (I-IV), and identified OI I and IV to be caused by an autosomal-dominant gene and OI II and III to be caused by an autosomal-recessive gene, but the exact gene sequences responsible had not yet been determined. ${ }^{2}$ Advances in the field of genetics have made it easier to characterize genetic sequences, and the genes linked to the development of OI have since been identified for all of the four originally defined types of $\mathrm{OI}$, in addition to several of the more recently classified types. ${ }^{3}$ This has been a major step in the advancement of clinical treatments for OI, as it is easier to identify and generate appropriate animal models for OI research by targeting specific genetic defects. 


\section{Ol types I-IV}

\section{Characteristics in humans}

When OI was first categorized into types I-IV, the description that was given to type I was "dominantly inherited OI with blue sclerae", and included such characteristics as having a history of broken bones from a very young age, bowing of long bones in lower extremities, bruising easily, and hearing impairment. ${ }^{2}$ Additional features observed in persons with OI I include being of normal height or slightly short in stature and not suffering from dentinogenesis imperfecta (DI). ${ }^{4} \mathrm{OI}$ II was labeled "lethal perinatal OI with radiographically crumpled femora and beaded ribs", and was characterized as being a fatal condition either in utero or shortly after birth. ${ }^{2}$ Features observed in individuals with OI II include multiple fractures at birth, obvious deformities, flattened long bones, and dark sclerae. ${ }^{3}$ OI III, referred to as "progressively deforming OI with normal sclerae", was characterized as having normal sclerae, distorted and fragile bones that progressively degenerated over time, ligament hypermobility, and a predisposition to DI. ${ }^{2}$ Also, individuals with OI III tend to be very short in stature and have a triangular face and severe scoliosis. ${ }^{3}$ Finally, OI IV was originally classified as "dominantly inherited OI with normal sclerae", and had similar defining characteristics to OI I, but with normal sclerae, reduced likelihood of spontaneous bone fractures, and no hearing loss. ${ }^{2}$

Therefore, in terms of severity, OI I-IV are ordered II $>$ III $>$ IV $>$ I. Although OI I-IV are vastly different in how they affect humans, they all have a similar genetic basis. ${ }^{4}$ Specifically, OI I is caused by a premature stop codon in COL1A1 and OI II-IV are caused by glycine substitutions in either the pro- $\alpha_{1}(\mathrm{I})$ or pro- $\alpha_{2}$ (I) collagen chains of COL1A1 or COL1A2. ${ }^{3}$ It has been determined that the phenotypes for OI I-IV depend on the location of the mutation in the COL1A1 and COL1A2 genes; however, several different mutations occurring at different points in the sequence can lead to the same phenotype of OI. ${ }^{5}$

\section{Animal models \\ Mov-13 mouse: OI I and II}

The Mov-13 mouse was first created by blocking transcription of the COL1A1 gene by integrating the Moloney leukemia virus at the $5^{\prime}$ end of the gene in what was referred to as the Mov-13 locus, ${ }^{6}$ later shown to be the murine equivalent to human Colla1. ${ }^{7}$ The Mov-13 mutation in mice results in a failure to produce type I collagen..$^{8-10}$ The homozygous $\left(\mathrm{Mov}-13^{-/}\right.$) form of this mutation is lethal to mice. ${ }^{6,7,9}$
Therefore, the Mov-13 ${ }^{-/-}$mouse is considered a model for OI II, ${ }^{11}$ but unfortunately it is unable to duplicate properly the development seen in humans. ${ }^{12}$

The heterozygous Mov-13 mutation (Mov-13/+) is associated with a reduced amount of collagen in soft connective tissue, increased hearing loss over time, and a substantial reduction in both mechanical and material properties of long bones similar to that seen in humans affected by OI I. ${ }^{13} \mathrm{~A}$ disorganized cortical lamellar structure in Mov-13/ ${ }^{/+}$mice has been observed, ${ }^{12}$ with a $22 \%-25 \%$ reduction in tissue-bending strength due to disrupted damage accumulation mechanisms in Mov- $13^{/+}$cortical bone. ${ }^{14}$ While Mov- $13^{/+}$exhibits a $50 \%$ decrease in type I collagen production, the collagen that is produced has normal amounts of both pro- $\alpha_{1}(\mathrm{I})$ and pro- $\alpha_{2}(\mathrm{I})$ chains, ${ }^{13,15}$ making Mov-13 ${ }^{/+}$mice a proper model for OI I in humans. ${ }^{16}$

\section{oim mouse: OI I and III}

One animal model of OI not created through the process of genetic engineering is the OI murine (oim) model. (The other five naturally occurring mutations are the G208A Col1a1 Golden Retriever, Col1a2 frameshift Beagle, SerpinH1 Dachshund, Chi zebrafish, and $\mathrm{Frf}^{-/}$zebrafish.) It was produced in the Jackson Laboratory (Bar Harbor, ME, USA) as a result of breeding $\mathrm{C} 3 \mathrm{H} / \mathrm{HeJ}$ and $\mathrm{C} 57 \mathrm{BL} / 6 \mathrm{JLe}$ mice. ${ }^{12}$ The mice present a spontaneous mutation in type I collagen structure with a deficiency of the pro- $\alpha_{2}(\mathrm{I})$ chain, and exhibit phenotypic and biochemical features typical of the most debilitating, nonlethal forms of OI. ${ }^{12}$ Characteristics observed in the homozygous oim mice (oim/oim) include susceptibility to fractures from a very young age, severe osteopenia, cortical thinning, bowing of long bones, bone deformities, joint laxity, small body size, and kyphosis. ${ }^{12}$ Their bones have altered collagen cross-links, ${ }^{17}$ reduced mineral size and heterogeneity, ${ }^{18}$ reduced lamellar structure, ${ }^{19}$ and increased vascular and osteocyte lacunar density. ${ }^{20} \mathrm{oim} / \mathrm{oim}$ bones have inferior mechanical properties compared to wild-type $(+/+)$ counterparts. ${ }^{17,20-22}$ Reduced fracture toughness, with a flat crack path and quick propagation, has been observed in these bones. ${ }^{17}$ Similar characteristics have also been observed in OI III in humans, ${ }^{23-26}$ for which the oim/oim mouse is a model. ${ }^{12}$ Compared to oim/oim, the heterozygous oim mouse $\left(\mathrm{oim}^{++}\right)$ does not experience spontaneous fractures, but does have bone material properties that lie in between those found in oim/oim and wild-type mice, and is thus considered a model of OI I in humans. ${ }^{27}$

Not only bones but also tendons are weaker in the oim mouse, as they are composed of collagen type I. Tensile 
testing performed on the tail tendons of $\mathrm{oim} / \mathrm{oim}$ and $\mathrm{oim}^{+}$ mice revealed a twofold reduction in the ultimate tensile strain compared to wild-type mice. ${ }^{28}$

\section{G6I0C mouse: OI I and IV}

In 2004, the Cre/Lox strategy, a method for genetically engineering animals for biomedical research, was combined with embryonic stem cells to mutate a section of murine Col1a2 in the stem cells, resulting in G610C-positive stem cells that were then injected into the mouse strain C57BL/6J (B6) blastocysts. ${ }^{29}$ Mice in the founder generation that retained the neomycin-targeting vector were termed $\mathrm{Neo}^{+}$ mice, and offspring from founder-generation males with Cre recombinase-expressing females were called $\mathrm{Neo}^{-}$mice. ${ }^{29}$ The founder line of $\mathrm{G} 610 \mathrm{C}$ mice was homozygous, and is now commonly known as $\mathrm{G} 610 \mathrm{C} / \mathrm{G} 610 \mathrm{C}^{\mathrm{Neo+}}$, whereas heterozygous mice are known as $+/ \mathrm{G} 610 \mathrm{C}^{\mathrm{Neo}+} .{ }^{11}$ The common name for the $\mathrm{Neo}^{-}$mouse $\left(+/ \mathrm{G} 610 \mathrm{C}^{\mathrm{Neo}-}\right)$ is the Amish mouse, because it models a large human Amish population consisting of 64 individuals exhibiting OI I/IV in both genetic code and phenotypic expression. ${ }^{11,29}$ Phenotypic characteristics of the mutant mice include decreased body weight, bone mineral density, and bone volume. ${ }^{29}$ Additionally, a four-point bending test of femora indicated a decrease in mechanical properties with reduced stiffness, postyield ultimate displacement, failure load, and energy to failure compared to wild type. ${ }^{29}$ Therefore, G610C/G610C ${ }^{\mathrm{Neo}+}$, +/G610C ${ }^{\mathrm{Neo}+}$, and +/G610C $\mathrm{Ceo}^{\mathrm{Ne}}$ are all acceptable models of OI IV, and $+/ \mathrm{G} 610 \mathrm{C}^{\mathrm{Neo+}}$ is also considered a model for OI I. ${ }^{11}$

\section{G859C Collal mouse: OI II}

In 1988, a site-directed mutagenesis approach was used to prepare transgenic mice expressing a mutated COL1A1 gene that resulted in perinatal death. ${ }^{11,30}$ The mutation was introduced to $C O L 1 A 1$ at residue 859 in the triple helical domain of the gene. ${ }^{11,30}$ Inspection of fetuses' radiographs showed short and wavy ribs, poor bone mineralization, underdeveloped skeletons, and pliable limbs. ${ }^{11,30}$ There were also large cavities noted in the bones of the mice, indicating that a high level of resorption had occurred. ${ }^{11,31}$ Due to the disease characteristics expressed in the G859C mutagenic mice, they have been accepted as a model for OI II. ${ }^{11}$

\section{Aga2 mouse: OI II and III}

A strain of mutagenic mice produced according to the standards of the German Mouse Clinic (http://www.mouse clinic.de), a system for the phenotyping of mutant mouse lines, ${ }^{32}$ was created using the Munich $N$-ethyl- $N$-nitrosourea mutagenesis protocol. ${ }^{11,33}$ This new line was called the Aga2 (abnormal gait 2) mouse, as the Aga $2^{/+}$mice that were first produced exhibited an abnormal gait as a result of excessive hind-limb deformity. ${ }^{33}$ The heterozygous $\left(\mathrm{Aga}^{/+}\right)$mice expressed a range of phenotypic variation from skeletal deformities, fractures, fragility, disorganized trabecular bone and collagen structure, and osteopenia to perinatal death. ${ }^{33}$ Aga $2^{/+}$mice that did not survive were classified as phenotypically similar to OI II. ${ }^{33}$ Homozygous (Aga2 $2^{-/-}$) mice that were produced from inter se breeding of $\mathrm{Aga}^{\prime+}$ males and females all died in utero around embryonic stage E9.5. ${ }^{33}$ Although the original research published on the Aga 2 mice did not say which types of OI the $\mathrm{Aga} 2^{/+}$mice that survived to adulthood and the $\mathrm{Aga}^{-/-}$mice were similar to, they have since been considered to be appropriate models for OI III and II, respectively. ${ }^{11}$ However, it needs to be noted that although the mutation affects Colla1, there has not yet been an equivalent genetic mutation identified in humans. ${ }^{11}$

\section{Brtlll and BrtllV mice: OI II and IV}

In 1999, two phenotypes of mice were created using the Cre/ Lox system. ${ }^{34}$ Initially, the researchers' intent was to use a recombination strategy to substitute a cysteine for glycine at position 349 in type I collagen and create a mouse model of OI I, but the floxed stop-cassette placement instead led to the expression of an allele that was supposed to be suppressed. ${ }^{34}$ Two chimeric males were obtained from this process, and after being mated with wild-type females, the resulting offspring that expressed the heterozygous mutation were described as having similar weight and size as healthy littermates, but they all died within hours of birth, and X-rays and skeletal staining revealed that they had multiple rib fractures, short vertebral bodies, and poor skull mineralization. ${ }^{34}$ Due to the fact that the phenotype expressed in these mice was similar to OI II in humans, this initial strain of mice was named Brittle II (BrtlII). ${ }^{34}$

To remove the stop cassette that led to the BrtlII phenotype, the two chimeric males were mated with EIIa-Cre mice, a strain of mice carrying a transgene mediated by the adenovirus EIIa promoter to target Cre-recombinase expression, and the resulting male founder-generation offspring that expressed the heterozygous mutation (F1-mosaic) were mated with wild-type $\mathrm{CD} 1$ and $\mathrm{C} 3 \mathrm{H} / \mathrm{HeJ}$ female mice to produce an F2 generation. ${ }^{34}$ There was large variability in phenotype noted in the mutant F2 mice, ranging from perinatal death to long-term survival, and their bones exhibited deformities, fragility, osteopenia, and a disorganized trabecular structure. ${ }^{34}$ These heterozygous mutant mice expressed the 
mutation that had been desired in the original recombination strategy, and were termed BrtlIV mice. ${ }^{34} \mathrm{BrtlIV}^{/+}$mice have geometrically smaller bones with reduced cortical width and lower trabecular thickness and bone-volume density compared to wild-type mice, increasing their vulnerability to fracture. ${ }^{35}$ Femoral elastic modulus, strength, and stiffness increase after puberty independently of the whole-bone geometry in BrtlIV ${ }^{/+}$mice with values comparable with wildtype mice. ${ }^{16}$ This strengthening is due to an increase in the material properties of the extracellular matrix without any typical corresponding structural adaptations, which means that $\mathrm{BrtlIV}^{/+}$mouse femora still have a geometric organization that is less resistant to applied loads. ${ }^{16}$ Mice also showed decreased molar volume and mineralized tissue volume in the teeth, although enamel properties were normal. ${ }^{36}$ The BrtlIV mice are heterozygous mice $\left(\right.$ BrtlIV $\left.^{\prime+}\right) ;{ }^{34}$ however, there is also a homozygous (BrtlIV/BrtlIV) type that exhibits a much milder form of OI than BrtlIV ${ }^{/+} .11,37$

\section{Human COLIAI-minigene mouse: OI II-IV}

A transgenic animal model of OI was produced by generating a minigene construct composed of sequences extracted from human $C O L 1 A 1$ that were missing a central region containing 41 exons, ${ }^{38,39}$ encompassing exons $6-46 .{ }^{40}$ The construct resulted in shortened pro- $\alpha_{1}$ (I) chains that ultimately prevented folding of the protein into a triple helix, leading to a lethal form of OI. ${ }^{38,39}$ Without proper folding, degradation of the three chains through procollagen suicide occurs, and leads to the depletion of normal pro- $\alpha$ (I) chains. ${ }^{39,41}$ Mice expressing high levels of the minigene exhibit a perinatal mortality rate up to $90 \% .{ }^{41}$ However, mice that only express a moderate minigene level tend to have a less severe phenotype, including low bone mineral density and collagen content, and a susceptibility to fractures. ${ }^{38}$ Therefore, human COL1A1minigene mice can be considered a model for OI II-IV. ${ }^{11,38}$

\section{G208A Collal Golden Retriever: OI III}

Another naturally occurring animal model of OI is the G208A Colla1 Golden Retriever, which was observed in a 12-weekold puppy that presented with DI and multiple bone fractures, including ribs and long bones. ${ }^{11,42,43}$ Samples of collagen type I taken from the puppy's skin showed that the collagen was not functioning normally. ${ }^{42,43}$ After it was determined that the puppy had naturally inherited a canine form of OI, samples of COL1A1 from both a healthy canine and the puppy with OI were sequenced and compared, and it was determined that the puppy's OI was due to a substitution of alanine for glycine at amino acid position $208 .{ }^{43}$ The location of the mutation is the namesake for this model, and because it is a naturally occurring mutation it is likely that the mutation is a heritable trait and could be reproduced in other dogs. However, the puppy used in these studies remains the only published case of this mutation having occurred in a canine.

\section{Colla2 frameshift Beagle: OI III}

The second naturally occurring canine model of OI was identified with the discovery of a heterozygous COL1A2 frameshift mutation in the complementary DNA (cDNA) of a proband Beagle (CU3) exhibiting a history of multiple long-bone fractures and overhydroxylated type I collagen. ${ }^{42,44}$ Four nucleotides (3991-3994) were deleted and replaced, with nine in the $C O L 1 A 2$ region responsible for coding for the $\mathrm{C}$-propeptide of the pro- $\alpha_{2}(\mathrm{I})$ chain. ${ }^{44} \mathrm{C}$-propeptides are essential for proper triple-helix formation, and mutations can lead to altered $C O L 1 A 1$ structure. ${ }^{45}$ Also, the 30 -amino acid code for human and canine pro- $\alpha_{2}(\mathrm{I})$ sequences normally has $100 \%$ identity, which suggests the CU3 Beagle is a good model for human OI III. ${ }^{46}$

\section{Med $^{-1-}$ zebrafish: OI I-IV}

In 1996 a homozygous mutant zebrafish was characterized as having curtain-like waves in its fin epithelium and was termed "microwaved" $\left(\mathrm{Med}^{-/-}\right) .{ }^{47}$ Fish with this mutation also exhibit delayed bone ossification, undulation of the larval fin, and severe reduction in bone density. ${ }^{48}$ One of the constituents of zebrafish bone, actinotrichia, is partially formed by type I collagen, and Colla1 has been identified in actinotrichia-forming cells. ${ }^{49}$ Additionally, gene sequencing has been confirmed that $\mathrm{Med}^{-/-}$zebrafish exhibit an alaninefor-glycine substitution at position 888 in their cDNA, which is predicted to result in the substitution of a glutamic acid for a lysine. ${ }^{48}$ This illustrates the validity of Med zebrafish as a model for OI I-IV. ${ }^{48}$

\section{Chi zebrafish: OI I-IV}

Another zebrafish that serves as a model for OI is the Chihuahua (Chi) mutant. This mutation can occur either in heterozygous $\left(\mathrm{Chi}^{/+}\right)$or homozygous (Chi/Chi) form, but there has not been a phenotypic difference noted between the two. ${ }^{50}$ It has, however, been determined that the mutation causes defective bone growth, with characteristics similar to those found in humans with OI. ${ }^{3,50}$ Radiographs show distorted bones with irregular radiodensity as early as 1 month of age. ${ }^{50}$ The Chi mutation occurs at position 2207 in the cDNA, where the wild-type sequence is unaltered, but there is a base-pair change that causes a missense mutation and 
changes the encoded amino acid from glycine to aspartate. ${ }^{50}$ The sequence of zebrafish COL1A1 is approximately $76 \%$ identical to the human gene, making it a good model for OI caused by $C O L 1 A 1$ mutations., ${ }^{3,50}$

\section{Ol types V-VIII}

\section{Characteristics in humans}

In 2004, it was suggested that three new phenotypes be added to the classification of OI and referred to as OI V-VII. ${ }^{4} \mathrm{~A}$ few years later, another phenotype was proposed and classified as OI VIII. ${ }^{51}$ The features of the disorder classified as OI V include being slightly to moderately short in stature, with a dislocated head of the radius, a mineralized interosseous membrane, and normal sclerae. ${ }^{4}$ Characteristics of OI VI include moderately short stature, presence of scoliosis, accumulation of osteoid in bone as well as a fish-scale bone-lamellation pattern, normal sclerae, and absence of DI. ${ }^{4}$ Traits described for OI VII include slightly short stature with shortened humeri and femora, decreased angle between the head and shaft of the femora, normal sclerae, and no presence of DI. ${ }^{4}$ Finally, the characteristics of the severeto-fatal disease known as OI VIII include normal sclerae, bulbous metaphyses, and extremely short stature with very low bone mineralization. ${ }^{51}$

Genetic causes of OI V-VII were unknown at the time it was proposed that they be added under the classification of OI, but have since been identified. In 2013, it was suggested that the expression of $\mathrm{OI} \mathrm{V}$ is caused by a mutation in the IFITM5 gene, ${ }^{52}$ which encodes a transmembrane protein important to osteoblast expression. ${ }^{53}$ A mutation in the SERPINF1 gene was identified as the cause of OI VI. ${ }^{54} \mathrm{~A}$ genetic link between the decreased expression of CRTAP and the presence of OI VII had been discovered. ${ }^{55}$ A genetic mutation caused by defects in the $P 3 H 1 / L E P R E 1$ gene resulted in an osteopathic disease with OI-type characteristics, ${ }^{51}$ later classified as OI VIII. ${ }^{56}$

\section{Animal models}

\section{Ifitm5 transgenic mouse: OIV}

A mouse model with IFITM5 mutation was very recently created by first placing murine Ifitm 5 cDNA under a Col1a1 $2.3 \mathrm{kB}$ promoter, and then using mutagenesis to achieve the correct mutation (c. $-14 \mathrm{C}>\mathrm{T}$ ) that occurs in humans. ${ }^{53}$ Mice that inherited mutant Ifitm 5 had severe skeletal deformities, as well as perinatal death. ${ }^{53}$ Additionally, the limbs of the mice lacked growth abnormalities, but they were facing downward at birth, and skeletal samples taken at E15.5 and E18.5 showed a consistent delay in mineralization. At E18.5 there was also the presence of forelimb and hind-limb fractures in utero, as well as extreme deformities of the rib cage. ${ }^{53}$

\section{Pedf ${ }^{--}$mouse: OIVI}

Mice genetically modified to be deficient in Pedf were first created by replacing exons 3-6 of SERPINF 1 with a cassette comprised of an internal ribosomal entry site, $\beta$-galactosidase genes, and neomycin-resistance genes. ${ }^{57}$ After it was discovered that OI VI in humans is caused by mutations in SER$P I N F 1$, this procedure was replicated to produce $\mathrm{Pedf}^{-/-}$mice for the purpose of studying the role of $P E D F$ in bone and other tissues. ${ }^{58}$ Bending tests performed on femora from wild-type and $\mathrm{Pedf}^{-/}$mice indicated that while the ultimate force applied to both groups was about the same, the ultimate displacement in the $\mathrm{Pedf}^{-/}$bone was approximately half of that in wild-type bone, with the energy of failure being $25 \%$ lower in the Pedf $^{-/}$mice. ${ }^{58}$ Through this study, it was determined that $\mathrm{Pedf}^{-/-}$mice are a suitable model for OI VI. ${ }^{58}$

\section{Crtap $^{-1-}$ mouse: OIVII}

Around the same time that the genetic cause of OI VII in humans was linked to a deficiency in CRTAP expression, a strain of homozygous Crtap-deficient $\left(\mathrm{Crtap}^{-/-}\right)$mice was produced using a homologous recombination approach. ${ }^{59,60}$ It has been found that $\mathrm{Crtap}^{-/-}$mice properly model OI VII in humans, as they have an abnormally high mineral content and increased mineral densities in their bones compared to wild-type mice. ${ }^{60}$ Other characteristics noted in $\mathrm{Crtap}^{-/}$mice include a progressive severe kyphoscoliosis, low bone density, and cartilage dysplasia. ${ }^{11}$ However, Crtap $^{-/}$mice tend to have a less severe form of the disease than is found in most humans. ${ }^{11,56}$ Tensile testing done on the skin of $\mathrm{Crtap}^{-/-}$mice showed that the peak load and stiffness of the tissue were $60 \%$ lower than the skin of wild-type mice. ${ }^{61}$

\section{P3h I- mouse: OI VIII}

In 2010, a method of homologous recombination was used to create a $P 3 H 1$-knockout mouse by targeting exons 1-3 of $\mathrm{P} 3 \mathrm{H1} .^{62}$ The heterozygous $\left(\mathrm{P} 3 \mathrm{~h} 1^{+}\right)$mice did not express

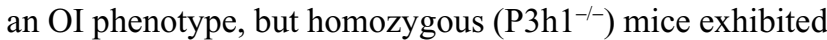
significantly smaller body size, lower mineral density in the skull and long bones, progressive kyphoscoliosis, and shorter femora that had decreased stiffness and failure load compared to wild-type littermates. ${ }^{62} \mathrm{P} 3 \mathrm{~h} 1^{-/-}$mice also demonstrate elevated auditory thresholds and altered morphology of the middle-ear bone joints, which make them an ideal model for investigating the mechanisms that cause hearing loss in OI patients. ${ }^{63}$ 


\section{Ol types IX and $X$}

\section{Characteristics in humans}

Recently, there have been several new genetic mutations identified that lead to a disorder similar to OI, and a few have been subsequently classified as OI types IX and X. $P P I B$ was identified as the gene responsible for OI IX after patients initially diagnosed with OI II-IV were not found to have mutations present in COL1A1 or COL1A2. ${ }^{64}$ In fact, multiple studies have shown that although the mutation occurs in PPIB, the phenotype expressed is similar to classical OI type II, III, or IV. ${ }^{6467} \mathrm{OI} \mathrm{X}$, by comparison, is far less broad in its phenotype: the available data were obtained from a study of a single patient who exhibited small bone size, blue sclerae, multiple fractures, malformed bones, and DI. ${ }^{68}$ The gene identified as causing the OI in this patient was HSP47/SERPINH1, ${ }^{68}$ which is a molecular chaperone required for the maturation of collagen types I and IV in the endoplasmic reticulum (ER). ${ }^{69,70}$

\section{Animal models Ppib $^{-1-}$ mouse: OI IX}

Between 2006 and 2007, several research articles were published indicating the roles of P3h1 and Crtap in the development of OI in humans and mice. ${ }^{51,55,59,71}$ There was also a relationship established between P3h1, Crtap, and Ppib, ${ }^{59,62,71,72}$ and it was found that they interact to form a complex in the rough ER that is believed to function as a collagen chaperone. ${ }^{72}$ To investigate this relationship further, the Cre/Lox system was utilized to create a PPIB-knockout mouse by targeting exon 3 through homologous recombination. ${ }^{11,71}$ The heterozygous $\mathrm{Ppib}^{+/-}$mice that were produced using this technique did not exhibit any symptoms of OI, and were mated to produce $\mathrm{Ppib}^{-/}$offspring, ${ }^{71}$ which instead exhibit symptoms of OI, including decreased body size and weight, low bone mineral density and volume, progressive kyphosis, decreased skin stiffness, and increased laxity. ${ }^{11,71}$ Although the phenotype observed in the $\mathrm{Ppib}^{-/-}$mice is less severe than in humans, it is considered an appropriate model of OI IX. ${ }^{11}$

\section{Serpinh I (Hsp47 ${ }^{--}$) mouse: OI X}

An HSP 47-knockout mouse was created in 2000 as the result of a gene-targeting approach. ${ }^{73}$ While first-generation heterozygous $\left(\mathrm{Hsp} 47^{/+}\right)$mice displayed no apparent OI phenotype, second-generation homozygous (Hsp47 $7^{-/}$) embryos did not survive past E11.5, and displayed ruptured blood vessels and abnormally oriented epithelial tissues. ${ }^{73}$ Mutant embryos were more translucent than wild-type mice, and appeared shortened. ${ }^{73}$ Although Northern blot analysis showed that Hsp47 messenger RNA was lower in Hsp47 $7^{/ 4}$, it was not expressed at all in Hsp47 $7^{-/-}$mice. ${ }^{73}$ Electron microscopy observations of collagen fibrils secreted by Hsp $47^{-/-}$cells showed thin fibrils forming abnormal branches, thus indicating that the collagen type I secreted from the Hsp $47^{-/}$mouse cells could not form normal supramolecular fibrillar structures. ${ }^{70}$ It is believed that $\mathrm{Hsp} 47$ plays an important role either in preventing the collagen triple helix from unfolding and providing stabilization during the progression of procollagen folding, or in preventing lateral association of procollagen triple helices in the ER. ${ }^{73,74}$

\section{Serpinh I (L326P) Dachshund: OI X}

Dachshunds exhibiting multiple fractures and history of lameness were found to have different long bones, ribs, mandibles, and teeth from normal. Their long bone exhibited thin cortical bone lacking an organized Haversian system and secondary cancellous bone, and their teeth had a thin dentine layer. ${ }^{75}$ A homozygosity-mapping approach determined the position of the mutation responsible for these abnormalities to be located at 24.66-29.4 Mb interval where the SERPINH1 gene maps. ${ }^{76}$ The Serpinh1 Dachshund does not share an equivalent mutation noted in humans, but its phenotype makes it a suitable model for OI X. ${ }^{11}$ Drögemüller et $\mathrm{al}^{76}$ suggested the SERPINH1 canine mutation could be a valuable model for the identification of a fifth gene, in addition to COL1A1, COL1A2, CRTAP, and LEPRE1, that generates OI in humans.

\section{OI types XI-XVII}

\section{Characteristics in humans}

Since 2010, there have been an additional seven new OI types with similar phenotypes to but different genetic bases from the original four types of OI added to the OI-classification system. It was proposed that the syndrome resembling OI known as Bruck syndrome 1 be reclassified as $\mathrm{OI}^{77,78}$ following research that identified a mutation in the FKBP10 gene as the cause of a recessive form of OI with characteristics similar to OI III. ${ }^{79}$ This phenotype is now known as OI XI, and the suspected mechanism of the FKBP10 mutation is that it causes a decrease of collagen type I deposition in the extracellular matrix. ${ }^{66}$

OI XII has been identified in a single proband with a phenotype similar to OI IV, but the cause of this OI type was linked to a frameshift mutation occurring in the $S P 7$ gene. ${ }^{80}$ OI XIII was identified as being caused by a homozygous missense mutation in the gene that encodes the BMP1/Toll-like proteinases, 
and results in a phenotype similar to OI III. ${ }^{81}$ OI XIV was first described when a homozygous mutation in the TMEM38B gene was found to lead to a phenotype with characteristics in line with an autosomal-recessive type of OI, including osteopenia and fractures of varying severity, but normal teeth, sclerae, and hearing. ${ }^{82}$

What is now known as OI XV was described in several publications when multiple mutations in the WNT1 gene were found in individuals displaying phenotypes characteristic of OI III-IV. ${ }^{83-86}$ OI XVI has been documented in one proband family where two siblings were affected by severe OI characterized by frequent fractures starting in utero, varus deformities of the legs, soft skull bones with large fontanels, and beaded ribs ${ }^{87}$ Analysis of DNA from one sibling indicated a homozygous deletion in the $C R E B 3 L 1$ gene. ${ }^{87}$ OI XVII was classified after two individuals diagnosed with OI IV were found to have a mutation in the SPARC gene. ${ }^{88}$

\section{Animal models}

\section{Fkbp I0-- mouse: OI XI}

Mice containing the European conditional mutagenesis allele were created to study the function of Fkbp $10{ }^{89}$ In the first generation of heterozygotes $\left(\mathrm{Fkbp10} 0^{/+}\right)$, no OI phenotype was noted. ${ }^{89}$ However, homozygotes $\left(\mathrm{Fkbp} 10^{-/-}\right)$obtained from breeding Fkbp $10^{/+}$mice exhibited delayed growth from E13.5 on, as well as downward-facing forelimbs, fragile tissue, flattened facial features, ER dilation caused by accumulation of abnormal procollagen chains in the ER, and perinatal death. ${ }^{89}$ While humans with OI XI do not exhibit perinatal death, the effect the mutation has on the ER and collagen formation is phenotypically similar to Fkbp $10^{-/-}$mice. ${ }^{89}$

\section{Osterix-null Sp7 $7^{---}$mouse: OI XII}

One initial method to create an Sp7-null mouse involved using a homologous recombination of embryonic stem cells to create nonphenotypic heterozygous $\left(\mathrm{Sp} 7^{+/-}\right)$mice. ${ }^{90}$ However, Sp7-null offspring obtained from $\mathrm{Sp} 7^{+/-}$pairings all died within 15 minutes of birth following difficulty breathing, and exhibited severe limb deformities. ${ }^{90}$ A second method used the Cre/Lox system to create conditional SP7-knockout mice with Colla1-Cre $\left(\mathrm{Osx}^{\mathrm{Flox}^{-}}\right.$;Colla1-Cre), which were designed to inactivate SP7 without perinatal lethality. ${ }^{91}$ $\mathrm{Osx}^{\mathrm{Flox}}{ }^{-}$;Col1a1-Cre mice exhibited decreased trabecular bone mineralization, as well as osteopenia and cortical bone thinning. ${ }^{91}$ Although both models existed before SP7 was linked to OI in humans, $\mathrm{Osx}^{\mathrm{Flox}}{ }^{-}$;Col1a1-Cre may possibly be considered a model for OI XII, but further studies are needed in this regard.

\section{Frf $^{-1}$ zebrafish: OI XIII}

It has been shown that mutations in $B M P 1$ cause high bone mineral density and multiple fractures in human OI XIII. ${ }^{48,81}$ This mutation in zebrafish, termed frilly fins $\left(\mathrm{Frf}^{-/}\right)$, causes a ruffled larval fin, short body axis, malformed craniofacial bones and vertebrae, and reduced ossification and bone density. ${ }^{48} \mathrm{Frf}^{-/-}$was created by missense substitutions in $B M P 1$, and led to osteoblasts exhibiting a more cuboidal structure than wild-type fish. ${ }^{48} \mathrm{Bmp} 1$ has been found to cleave and inactivate the Bmp2/4 inhibitor chordin, which aids in generating mature collagen type I, and thus it may disrupt osteogenesis when present at elevated levels. ${ }^{92}$

\section{Swaying (Wntl $\left.{ }^{\text {Sw/Sw }}\right)$ mouse: OI XV}

The Swaying ( $\mathrm{Sw}$ ) mouse was first described as having poor coordination, with a rotational movement pattern and cerebellar deficit. ${ }^{93}$ The Sw mouse was later found to be phenotypically similar to mice with a targeted WNT1 mutation causing osteopenia and fragile bones, ${ }^{94}$ and was subsequently determined to be caused by a frameshift mutation in WNT1 (Wnt1 ${ }^{\mathrm{Sw}}$ ), with homozygous (Wnt1 ${ }^{\mathrm{Sw} / \mathrm{Sw}}$ ) mice expressing the Sw phenotype. ${ }^{95}$ Following the classification of WNT1 mutations as a cause of documented $\mathrm{OI}$ in humans, $\mathrm{Wnt}{ }^{\mathrm{Sw} / \mathrm{Sw}}$ was proposed to be a suitable model for OI XV. ${ }^{96}$

Currently, there are no animal models for OI XIV, XVI, or XVII. However, the genes that were discovered to be the cause of OI XVI and XVII were selected for investigation based on genetic mutations in mice that cause similar phenotypes to what human cases presented with..$^{87,88}$

\section{Animal models in clinical research}

Bone fracture and fragility are the primary symptoms of OI, and thus clinical research on treatments has been focused mainly on understanding the bone properties of the animal models for $\mathrm{OI}$ and on regaining mechanical integrity in these bones. Most of the research dedicated to finding treatments for OI has primarily utilized mouse models of classical OI (Table 1).

\section{Pharmacological treatments}

Many studies have tested drug treatment as a clinical therapy for OI. In particular, bisphosphonates, a class of antiresorptive drugs, have been widely used to treat OI in an effort to reduce fracture incidence and improve bone density in OI patients. Between the different bisphosphonates, alendronate and pamidronate have been the most used in clinical studies run on animals. Short-term therapy studies conducted on oim/ oim and BrtlIV ${ }^{/+}$mice for both alendronate and pamidronate 
Table I Current animal models for human osteogenesis imperfecta (OI), with their genetic and phenotypic characteristics and clinical therapy applications

\begin{tabular}{|c|c|c|c|c|}
\hline Common name & $\begin{array}{l}\text { Human } \\
\text { Ol type }\end{array}$ & Gene & Characteristics & Clinical therapy \\
\hline \multicolumn{5}{|l|}{ Mouse models } \\
\hline Mov- $13^{-1-}$ & OI II & COLIAI & Perinatal mortality & Gene replacement \\
\hline Mov-13/+ & Ol I & COLIAI & $\begin{array}{l}\text { Hearing loss, reduced mechanical properties in bone, and } \\
\text { reduced collagen production }\end{array}$ & \\
\hline oim/oim & OI III & COLIA2 & $\begin{array}{l}\text { Fragile bones, osteopenia, cortical thinning, bone } \\
\text { deformities, joint laxity, kyphosis }\end{array}$ & $\begin{array}{l}\text { Bisphosphonate therapy, stem } \\
\text { cell transplantation, bone } \\
\text { marrow stromal cells, gene } \\
\text { supplementation, whole-body } \\
\text { vibration }\end{array}$ \\
\hline $\mathrm{oim}^{\prime+}$ & OII & COLIA2 & Decreased material properties of bone & \\
\hline G6I0C/G6I0C $\mathrm{Neo+}^{+}$ & OI IV & COLIA2 & $\begin{array}{l}\text { Decreased body weight, bone mineral density, bone } \\
\text { volume, and mechanical properties of bone }\end{array}$ & \\
\hline$+/ \mathrm{G} 610 \mathrm{C}^{\mathrm{Neo+}}$ & OI I/IV & COLIA2 & $\begin{array}{l}\text { Decreased body weight, bone mineral density, bone } \\
\text { volume, and mechanical properties of bone }\end{array}$ & \\
\hline$+/ G 610 C^{\mathrm{Neo}-}$ (Amish) & OI IV & COLIA2 & $\begin{array}{l}\text { Decreased body weight, bone mineral density, bone } \\
\text { volume, and mechanical properties of bone }\end{array}$ & \\
\hline G859C & OI II & COLIAI & $\begin{array}{l}\text { Short and wavy ribs, poor bone mineralization, } \\
\text { underdeveloped skeleton, pliable limbs, perinatal death }\end{array}$ & \\
\hline $\mathrm{Aga2}^{\prime+}$ & OI II/III & COLIAI & $\begin{array}{l}\text { Skeletal deformities, fragile bones, osteopenia, perinatal } \\
\text { death (in some cases) }\end{array}$ & \\
\hline $\mathrm{Aga2} 2^{-1-}$ & OI II & COLIAI & Embryonic mortality & \\
\hline BrtIII & OI II & COLIAI & $\begin{array}{l}\text { Rib fractures, short vertebral bodies, poor skull } \\
\text { mineralization, perinatal mortality }\end{array}$ & \\
\hline $\mathrm{BrtIIV}^{/+}$ & OI IV & COLIAI & $\begin{array}{l}\text { Perinatal death to long-term survival, bone deformity, } \\
\text { fragile bones, osteopenia }\end{array}$ & $\begin{array}{l}\text { Bisphosphonate therapy, sclerostin } \\
\text { antibody therapy, bone marrow } \\
\text { stromal cells }\end{array}$ \\
\hline $\mathrm{BrtlIV/BrtIIV}$ & $\begin{array}{l}\text { OI IV } \\
\text { (mild) }\end{array}$ & COLIAI & Bone deformity, bone fragility, osteopenia & \\
\hline $\begin{array}{l}\text { Human COLIAI } \\
\text { minigene }\end{array}$ & OI II-IV & COLIAI & $\begin{array}{l}\text { Fragile bones, low bone mineral density, } \sim 90 \% \text { perinatal } \\
\text { mortality rate (when high levels of minigene expressed) }\end{array}$ & $\begin{array}{l}\text { Bone marrow stromal cells, } \\
\text { oligonucleotide antisense gene } \\
\text { therapy }\end{array}$ \\
\hline Ifitm5 transgenic & Ol V & IFITM5 & $\begin{array}{l}\text { Skeletal deformities, fragile bones, poor bone } \\
\text { mineralization, perinatal death }\end{array}$ & \\
\hline Pedf ${ }^{-/}$ & Ol VI & SERPINFI & Decreased material properties of bone & \\
\hline Crtap $^{-1-}$ & OI VII & CRTAP & $\begin{array}{l}\text { High bone mineralization and mineral density in bone (but } \\
\text { low bone density), progressive kyphoscoliosis, cartilage } \\
\text { dysplasia, decreased material properties in skin }\end{array}$ & \\
\hline P3hI ${ }^{-1-}$ & OI VIII & LEPREI & $\begin{array}{l}\text { Small body size, low mineral density in calvarial and long } \\
\text { bones, decreased material properties of bone, impaired } \\
\text { hearing }\end{array}$ & \\
\hline $\mathrm{Ppib}^{-1-}$ & OIIX & PPIB & $\begin{array}{l}\text { Decreased body size and weight, low bone mineral density } \\
\text { and volume, progressive kyphosis, decreased material } \\
\text { properties in skin }\end{array}$ & \\
\hline Hsp47-I- & OIX & SERPINHI & Embryonic mortality & \\
\hline $\mathrm{Fkbp} \mathrm{O}^{-1-}$ & OI XI & FKBPIO & $\begin{array}{l}\text { Delayed growth beginning at EI } 3.5 \text {, fragile tissue, skeletal } \\
\text { deformities, perinatal mortality }\end{array}$ & \\
\hline $\mathrm{Sp} 7^{-1-}$ & $\begin{array}{l}\text { Possibly } \\
\text { OI XII }\end{array}$ & SP7 & $\begin{array}{l}\text { Decreased trabecular bone mineralization, osteopenia, } \\
\text { cortical bone thinning }\end{array}$ & \\
\hline Wnt I Iw/Sw (Swaying) & OI XV & WNTI & $\begin{array}{l}\text { Poor coordination, osteopenia, fragile bones, cerebellar } \\
\text { deficit }\end{array}$ & \\
\hline \multicolumn{5}{|l|}{ Canine models } \\
\hline $\begin{array}{l}\text { G208A Collal Golden } \\
\text { Retriever }\end{array}$ & OI III & COLIAI & Fragile bones, dentinogenesis imperfecta & \\
\hline Colla2 frameshift Beagle & OI III & COLIA2 & Fragile bones & \\
\hline SerpinHI (L326P) & OIX & SERPINHI & Fragile bones, lameness, thin cortical bone and dentine & \\
\hline Dachshund & & & & \\
\hline
\end{tabular}




\begin{tabular}{|c|c|c|c|c|}
\hline Common name & $\begin{array}{l}\text { Human } \\
\text { Ol type }\end{array}$ & Gene & Characteristics & Clinical therapy \\
\hline \multicolumn{5}{|l|}{ Zebrafish models } \\
\hline Med $^{-1-}$ & OI I-IV & COLIAI & $\begin{array}{l}\text { Delayed bone ossification and low bone mineral density, } \\
\text { larval fin undulation, curtain-like waves in fin epithelium }\end{array}$ & \\
\hline $\mathrm{Chi}^{i^{+}}$ & OI I-IV & COLIAI & Generalized defective bone growth & \\
\hline $\mathrm{Chi} / \mathrm{Chi}$ & OI I-IV & COLIAI & Generalized defective bone growth & \\
\hline $\mathrm{Frf}^{--}$ & OI XIII & BMPI & $\begin{array}{l}\text { Ruffled larval fin, short body axis, deformed craniofacial } \\
\text { bones and vertebrae, reduced ossification and bone } \\
\text { density }\end{array}$ & \\
\hline
\end{tabular}

injections showed a reduction in the fracture rate, ${ }^{97,98}$ with thicker and stiffer bones, ${ }^{99-101}$ enhanced density, ${ }^{97,99-101}$ but no mineral maturity, ${ }^{102}$ and variable biomechanical properties. ${ }^{97-99,101}$ In both models, bisphosphonate treatment altered the growth plate in mice by increasing their height, mainly at the proliferation and hypertrophic zones, reducing vascular invasion ${ }^{103}$ and growth-plate cell turnover, ${ }^{98}$ and with detrimental effects on osteoblasts and bone formation. ${ }^{99}$ In trabecular oim/oim bone, alendronate increased trabecular number, decreasing thickness and separation and increasing bone volume density, ${ }^{97,104}$ and produced no improvement in strength or mechanical properties. This shows that the reduction in fracture rate is primarily attributable to an increase in bone mass. ${ }^{104}$ High doses of alendronate were more effective in short-term therapy. ${ }^{98}$

Long-term alendronate therapy in growing oim/oim mice also appeared to be effective in increasing metaphyseal density. The increased length and bowing of tibia metaphysis seen in short-term therapy was not observed in long-term treatment, suggesting a dissipation of these effects over time. ${ }^{105}$ Sex was a factor contributing to the success of the treatment, as alendronate increased compositional heterogeneity in male mice, improving bone quality. ${ }^{106}$

More recently, alendronate treatment was proved to affect the fracture-healing process of bone in BrtlIV ${ }^{+}$mice positively. ${ }^{107}$ Mice treated with alendronate before and after fracture exhibited increased callus volume, with decreased mineralization quality and quantity, and increased bone volume and torque at failure. However, no effect was observed if the drug treatment was used only before fracture. ${ }^{107}$

RANKL inhibitors have shown promise in both human $^{108,109}$ and animal ${ }^{97,110-113}$ trials for the treatment of several different osteopathologies. When RANKL binds to RANK, it activates the pathway that leads to osteoclastogenesis, ${ }^{109,11-114}$ so the pharmacological application of RANKL inhibitors aims to prevent bone resorption by blocking the RANK pathway from being activated..$^{97,108-114}$ The inhibitor denosumab, a fully human monoclonal antibody, ${ }^{97,111-114}$ has a higher specificity and affinity for RANKL than osteoprotegerin, ${ }^{112-114}$ a naturally occurring decoy RANKL receptor. ${ }^{110-114}$ Unfortunately, denosumab is not recognized by murine RANKL, ${ }^{97,11-114}$ although preliminary studies done in primates ${ }^{97,112}$ and knock-in mice expressing murine/human RANK $^{97,113}$ have yielded positive results, including increased mineral content, density, and strength in primate bone, ${ }^{97,112}$ as well as suppressed resorption and increased density in human RANKL mouse bone ${ }^{97,113}$ following denosumab treatment.

The successful application of RANKL inhibitors in OI treatment was demonstrated in two children with OI VI who exhibited decreased bone resorption following administration of denosumab. ${ }^{109}$ Animal research of RANKL inhibitors in the treatment of OI has so far been limited to the use of RANK-Fc, ${ }^{97,110,111}$ a recombinant RANKL inhibitor with properties similar to osteoprotegerin..$^{97,110,114}$ The results of treating oim/oim mice with RANK-Fc show that it increases bone density, ${ }^{97,111}$ improves some mechanical and geometric properties of bone, ${ }^{11}$ delays callus remodeling following fracture, ${ }^{110}$ and reduces fracture incidence. ${ }^{97}$ Inspired by the success of the teriparatide (human parathyroid hormone) as an anabolic drug for osteoporosis, ${ }^{115-120}$ and as adjuvant for bone ${ }^{121,122}$ and allograft ${ }^{123-125}$ healing, scientists have recently tested teriparatide in adults with OI I-IV. ${ }^{126}$ Results showed an enhancement in vertebral bone mineral density and strength, and thus there is a need for animal research on the use of teriparatide for treatment of OI.

Finally, a study performed on BrtlIV ${ }^{/+}$mice determined the effect of sclerostin antibody (SA), an anabolic bone therapeutic, on OI bone formation. ${ }^{127}$ It was thought that SA could neutralize sclerostin, ultimately increasing bone formation by preventing the inhibition of anabolic canonical Wnt signaling. ${ }^{127}$ While previous antiresorptive bisphosphonatetreatment studies using BrtlIV ${ }^{/+}$and oim mice resulted in increased trabecular number but not thickness, the treatment study using SA instead found an increase in trabecular 
thickness but not number. ${ }^{127}$ After 2 weeks of SA therapy, $\mathrm{BrtlIV}^{/+}$mice had increased cortical and trabecular bone mass, reduced fragility in long bones, including improved stiffness, and the ability to withstand higher loads before breaking. ${ }^{127} \mathrm{SA}$ therapy increased the rate of bone formation, increasing both cortical and cancellous bone volume, and also improved the strength of cortical bone without affecting bone mineralization. ${ }^{127}$ Although more research is needed, SA treatments could eventually prove to be an effective therapy for patients with OI IV in the future.

\section{Stem cell transplantation}

The oim/oim mouse has recently undergone stem cell therapies to alter developing OI bone pathology. Mesenchymal stem cell (MSC) therapy for tissue regeneration can improve damaged or diseased tissue when delivered to relevant locations. ${ }^{128}$ MSCs injected into oim/oim mice from adult wild-type mice migrate to sites of new bone formation. ${ }^{129}$ As an expansion on this study, human fetal blood MSCs, collected by cardiocentesis under ultrasound guidance, were considered as a therapy for oim/oim mice. ${ }^{130,131}$ Virgin oim/oim females were mated with oim/oim males and then underwent intrauterine transplantation at E13.5-E15 so that each fetus could be injected intraperitoneally with human fetal blood MSCs. ${ }^{130}$ Offspring were analyzed at E18, week 1 after birth, and weeks 2, 4, 8, and 12 thereafter. At each point measured, findings showed a $70 \%$ reduction in the number of fractures with only $5 \%$ of cells ingrafted. ${ }^{130}$ The fetal blood stem/stromal cells engrafted into oim/oim bone differentiated into osteoblasts, producing osteocalcin and Colla2, which is absent in oim/oim mice. ${ }^{132}$ As a result, these bones showed a clinically relevant increase in cortical bone strength, length, and thickness, and clustered cells around sites of bone formation and repair, suggesting osteogenic differentiation. ${ }^{130,132}$

\section{Bone marrow stromal cells}

Studies involving the transplant of bone marrow stromal cells (BMSCs) from wild-type mice into human COL1A1minigene mice demonstrated that BMSCs could renew cells in multiple nonhematopoietic tissues, and may be a prospective treatment for OI. ${ }^{133}$ Transplanted BMSCs have been shown to contribute to bone formation in vivo and to improve the mechanical properties of the recipient bone. ${ }^{134}$ In a study conducted to determine the effect of transplanting BMSCs alone or suspended in a collagen matrix, BMSCs were harvested from the marrow of the femora and tibiae of wild-type mice syngeneic to oim mice, then cultured and injected into the femora of oim mice. ${ }^{134}$ Mechanical testing of the bone conducted 6 weeks after implantation found that femora injected with BMSCs suspended in collagen matrix were stronger than those injected with BMSCs alone, and that in both BMSC test groups treated bone was stronger when compared to oim/oim. ${ }^{134}$ Donor cells, tracked using green fluorescent proteins, differentiated into osteoblasts in vivo and actively participated in new bone formation. ${ }^{134}$ Histological analysis of the femora showed that those injected with BMSCs suspended in collagen matrix had more bone deposition than those injected with BMSCs alone. ${ }^{134}$ Comparison of the BMSC-treated samples with oim/oim samples indicated that all of the new bone deposition was a result of the combination of endogenous and exogenous cells. ${ }^{134}$

BMSCs may not only be transplanted between adult mice but also in utero and in developing animals. ${ }^{134,135}$ In another study, BMSCs were transplanted from long bones of adult cytomegalovirus/eGFP CD1 transgenic mice into embryos of wild-type females mated with BrtlIV ${ }^{/+}$males. ${ }^{135}$ Of the pups that reached weaning age, $51.4 \%$ were wild-type and $48.5 \%$ BrtlIV $^{/+}$mice, demonstrating a nearly equal survival rate between the two genotypes. ${ }^{135}$ Comparing these mice with a control group in which no treatments were administered, it was seen that BMSC treatment improved mechanical properties of bone in BrtlIV ${ }^{/+}$mice, ${ }^{135}$ with BMSC-treated BrtlIV ${ }^{/+}$ mice having significantly higher bone mineral density in both trabecular and cortical bone compared to untreated BrtlIV $^{/+}$mice. ${ }^{135}$

\section{Gene therapies}

Several methods have been proposed for implementing gene therapies in the treatment of OI, including gene replacement, antisense approaches, gene supplementation, and gene delivery to bone. ${ }^{136}$ One of the first studies in using animal models for gene replacement to treat OI was accomplished by transfecting a Col1a1-null allele taken from a Mov-13-- embryo with human $C O L 1 A 1 .^{137,138}$ In this case, functional collagen type I was formed in the mouse through transgene expression. ${ }^{137,138}$ This collagen was composed of two human $\alpha_{1}(\mathrm{I})$ and one mouse $\alpha_{2}$ (I) chains, suggesting that this could be a means for using gene therapy in treating OI in humans. ${ }^{137,138}$

Another approach of gene therapy is gene supplementation, which in OI research could consist of the delivery of Collal from healthy mice to a mouse with OI caused by a COL1A1 mutation. However, the challenge with this therapy is that most types of OI mutations are dominant-negative, meaning that the mutant allele disrupts the function of the normally functioning allele, so supplementation would not be 
effective without first blocking the expression of the mutant gene. ${ }^{136}$ Delivery of the healthy gene is further complicated by the fact that COL1A1 and COL1A2 are large genes and difficult to manipulate. ${ }^{138}$ The combination of gene supplementation with antisense gene therapy, a method of using antisense oligodeoxynucleotides, antisense RNA, or ribozymes to block transcription of certain gene sequences that are thought to cause the disease, ${ }^{139}$ could make gene therapy more feasible. ${ }^{136}$ One study involving linear oligonucleotide antisense therapy was done using human COL1A1-minigene mice. ${ }^{41}$ Mating mice where both parents expressed antisense minigene produced offspring that inherited both genes, and the rate of occurrence of the lethal fragile-bone phenotype was reduced from $92 \%$ to $27 \%$, demonstrating the effects of the therapy. ${ }^{41,140}$ One potential application for studying gene supplementation in an animal model is the use of the oim/ oim mouse, as the deletion of the COL1A2 in these mice stops incorporation of pro- $\alpha_{2}(\mathrm{I})$ chains into heterotrimers and leads to a buildup of pro- $\alpha_{1}(\mathrm{I})$ heterotrimers in tissue. ${ }^{136}$

One application of gene therapy that appears to hold a great deal of promise is gene delivery to bone. One way this can be done is through the use of noncoding RNA or a protein, which can be delivered using a vector, such as a virus. ${ }^{141}$ However, the use of viral therapy is not ideal in the clinical setting, due to the risks involved with it. ${ }^{142}$ Other studies have been performed to test the efficacy of gene delivery without a vector, as in one case using the delivery of naked plasmid DNA to the gastrocnemius of a wild-type ICR mouse. ${ }^{143}$ Unfortunately, although this method did lead to bone formation, it was determined that this was not an efficient method of gene delivery. ${ }^{142,143}$ Other methods, such as RNA interfacing and using synthetic carriers for delivery, have also been attempted, with varying degrees of success, ${ }^{142}$ and gene-delivery therapy still needs to be thoroughly tested before being safely implemented.

\section{Mechanical therapies}

Bone adapts both its mass and architecture to the mechanical loading applied upon it. ${ }^{144}$ Therefore, mechanical therapies that do not result in fracture and do not involve drugs are very attractive for application in the OI population. One potential mechanical therapy, whole-body vibration (WBV), has been studied in young oim/oim mice, and resulted in the improvement of trabecular and cortical bone morphologies during hind-limb growth. ${ }^{144} \mathrm{WBV}$ involves placing mice into a container on a vertically oscillating plate, which effectively introduces a vibrational mechanical stimulus to normal activities. ${ }^{145}$ Previous numerical studies have shown that increasing the frequency of the loading stimulus up to $30 \mathrm{~Hz}$ results in improved bone formation. ${ }^{146}$ Vanleene and Shefelbine utilized high-frequency, low-amplitude WBV in order to determine its effect on the volume and mechanical properties of young oim/oim bone. ${ }^{144}$ The study found that WBV caused an increase in oim/oim femoral and tibial cortical thickness and cross-sectional area, as well as an increase in trabecular bone volume in oim/oim tibiae. ${ }^{144} \mathrm{WBV}$ thus appears to be a potentially effective and safe treatment for increasing bone formation and possibly bone strength in OI. This therapy is particularly attractive for treating the growing skeletons of children with OI without the disadvantages of current longterm pharmacological therapies.

\section{Discussion and conclusion}

This review presented existing animal models for OI I-XVII and clinical therapies, some still emerging, that these models serve as a platform for OI research. Most of the animal models used for clinical trials were mice, representing moderate-to-severe conditions of the classic OI disease. In fact, mutagenesis studies that have led to the development of new models of OI have only been conducted using mice. The canine models of OI mentioned in this article all occurred spontaneously in animals that had not been bred for research purposes. It is probable that the bone structure of canines would more adequately model the disease physiology in humans than the bone structure of mice, but there are limiting factors that would make the development of canine OI models difficult. ${ }^{11}$

Currently, treatments for human OI rely largely on bisphosphonates and exercise management, which can increase the amount of bone but not its quality. ${ }^{37}$ More animal studies are needed to understand the actual efficacy and long-term effects of these treatments on bone, and also more research is envisaged to explore other therapies for the management and cure of OI. In this sense, animal models, and in particular mouse models of OI, offer an extremely valuable resource for the understanding of the disease and for the advancement of therapies for reducing fracture risk.

Mutagenic mouse models are relatively easy and quick to produce, and genetically assimilate mutations typical of human cases of OI. On the other hand, mouse bones are very small in size and do not allow for typical sample preparation as used in human bones (ie, milling out exact perfect beam samples from human bone for mechanical testing but not from a mouse bone, where the entire bone with its geometrical imperfections needs to be used). Also, the structure of mouse cortical bone is different from human cortical bone in that it is missing the 
Haversian system, as the whole mouse bone is about the size of a large osteon in human bone. This may have implications in terms of mechanics, because the lamellar osteonal structure is thought to provide toughness to human bone, ${ }^{147}$ although recent research on oim/oim mouse bone has shown that possibly the lamellar structure can yield a similar toughness to mouse bone. ${ }^{17}$ Apart from these two differences, mouse bone represents an indispensable resource to understand bone pathology and to anticipate the effects of potential therapies on humans, as mouse skeletal growth is accelerated, allowing for long-term investigation in a 6- to 12-month period.

In the future, there should be a much wider breadth of studies utilizing OI animal models for further understanding clinical applications and their translation to human therapies. It would be interesting to study methodological factors, such as drug dosage or mechanical loading, affecting treatment, and to investigate further long-term effects of treatment in each type of OI. Also, the combination of different therapies, such as using gene therapy with mechanical loading, may be a viable approach that needs further investigation. Therefore, more clinical studies should be conducted on the animal models presented here to determine which therapy holds the most promise for human OI. Finally, more studies allowing the direct translation of therapies from animal models to human cases should be put in place to facilitate implementation of new therapies.

\section{Disclosure}

The authors report no conflicts of interest in this work.

\section{References}

1. Baljet B. Aspects of the history of osteogenesis imperfecta (Vrolik's syndrome). Ann Anat. 2002;184(1):1-7.

2. Sillence DO, Senn A, Danks DM. Genetic heterogeneity in osteogenesis imperfecta. J Med Genet. 1979;16(2):101-116.

3. Kamoun-Goldrat AS, Le Merrer MF. Animal models of osteogenesis imperfecta and related syndromes. J Bone Miner Metab. 2007;25(4):211-218.

4. Rauch F, Glorieux FH. Osteogenesis imperfecta. Lancet. 2004; 363(9418):1377-1385.

5. Bodian DL, Chan TF, Poon A, et al. Mutation and polymorphism spectrum in osteogenesis imperfecta type II: implications for genotypephenotype relationships. Hum Mol Genet. 2009;18(3):463-471.

6. Jaenisch R, Harbers K, Schnieke A, et al. Germline integration of Moloney murine leukemia virus at the Mov13 locus leads to recessive lethal mutation and early embryonic death. Cell. 1983;32(1):209-216.

7. Harbers K, Kuehn M, Delius H, Jaenisch R. Insertion of retrovirus into the first intron of $\alpha 1(\mathrm{I})$ collagen gene to embryonic lethal mutation in mice. Proc Natl Acad Sci US A. 1984;81(5):1504-1508.

8. Barker DD, Wu H, Hartung S, Breindl M, Jaenisch R. Retrovirusinduced insertional mutagenesis: mechanism of collagen mutation in Mov13 mice. Mol Cell Biol. 1991;11(10):5154-5163.

9. Smith R. Osteogenesis imperfecta: from phenotype to genotype and back again. Int J Exp Pathol. 1994;75(4):233-241.
10. Iruela-Arispe ML, Vernon RB, Wu H, Jaenisch R, Sage EH. Type I collagen-deficient Mov-13 mice do not retain SPARC in the extracellular matrix: implications for fibroblast function. Dev Dyn. 1996;207(2):171-183.

11. Glorieux FH, Sponseller PD, Shapiro JR, Byers PH. Osteogenesis Imperfecta: A Translational Approach to Brittle Bone Disease. London: Academic Press; 2014.

12. Chipman SD, Sweet HO, McBride DJ, et al. Defective pro 2 (I) collagen synthesis in a recessive mutation in mice: a model of human osteogenesis imperfecta. Proc Natl Acad Sci USA. 1993;90(5):1701-1705.

13. Bonadio J, Saunders TL, Tsai E, et al. Transgenic mouse model of the mild dominant form of osteogenesis imperfecta. Proc Natl Acad Sci US A. 1990;87(18):7145-7149.

14. Jepsen KJ, Schaffler MB, Kuhn JL, Goulet RW, Bonadio J, Goldstein SA. Type I collagen mutation alters the strength and fatigue behavior of Mov13 cortical tissue. J Biomech. 1997;30(11-12):1141-1147.

15. Kuznetsova NV, Forlino A, Cabral WA, Marini JC, Leikin S. Structure, stability and interactions of type I collagen with GLY349-CYS substitution in $\alpha 1(\mathrm{I})$ chain in a murine osteogenesis imperfecta model. Matrix Biol. 2004;23(2):101-112.

16. Kozloff KM, Carden A, Bergwitz C, et al. Brittle IV mouse model for osteogenesis imperfecta IV demonstrates postpubertal adaptations to improve whole bone strength. J Bone Miner Res. 2004;19(4):614-622.

17. Carriero A, Zimmermann EA, Paluszny A, et al. How tough is brittle bone? Investigating osteogenesis imperfecta in mouse bone. J Bone Miner Res. 2014;29(6):1392-1401.

18. Fratzl P, Paris O, Klaushofer K, Landis W. Bone mineralization in an osteogenesis imperfecta mouse model studied by small-angle X-ray scattering. J Clin Invest. 1996;97(2):396-402.

19. Niyibizi C, Li F. Potential implications of cell therapy for osteogenesis imperfecta. Int J Clin Rheumtol. 2009;4(1):57-66.

20. Carriero A, Doube M, Vogt M, et al. Altered lacunar and vascular porosity in osteogenesis imperfecta mouse bone as revealed by synchrotron tomography contributes to bone fragility. Bone. 2014;61:116-124.

21. McBride D Jr, Shapiro J, Dunn M. Bone geometry and strength measurements in aging mice with the oim mutation. Calcif Tissue Int. 1998;62(2):172-176.

22. Camacho NP, Hou L, Toledano TR, et al. The material basis for reduced mechanical properties in oim mice bones. J Bone Miner Res. 1999;14(2):264-272.

23. Cole WG. The Nicholas Andry Award - 1996: the molecular pathology of osteogenesis imperfecta. Clin Orthop Relat Res. 1997;(343):235-248.

24. Cole WG. Advances in osteogenesis imperfecta. Clin Orthop Relat Res. 2002;(401):6-16.

25. Boyde A, Travers R, Glorieux F, Jones S. The mineralization density of iliac crest bone from children with osteogenesis imperfecta. Calcif Tissue Int. 1999;64(3):185-190.

26. Nyman JS, Reyes M, Wang X. Effect of ultrastructural changes on the toughness of bone. Micron. 2005;36(7):566-582.

27. Saban J, Zussman M, Havey R, Patwardhan A, Schneider G, King D. Heterozygous oim mice exhibit a mild form of osteogenesis imperfecta. Bone. 1996;19(6):575-579.

28. Misof K, Landis W, Klaushofer K, Fratzl P. Collagen from the osteogenesis imperfecta mouse model (oim) shows reduced resistance against tensile stress. J Clin Invest. 1997;100(1):40.

29. Daley E, Streeten EA, Sorkin JD, et al. Variable bone fragility associated with an Amish COL1A2 variant and a knock-in mouse model. $J$ Bone Miner Res. 2010;25(2):247-261.

30. Stacey A, Bateman J, Choi T, Mascara T, Cole W, Jaenisch R. Perinatal lethal osteogenesis imperfecta in transgenic mice bearing an engineered mutant pro- $\alpha 1(\mathrm{I})$ collagen gene. Nature. 1988;332(6160):131-136.

31. Bateman JF, Mascara T, Cole WG, Stacey A, Jaenisch R. The study of collagen structure and function by site-directed mutagenesis of collagen genes. Ann N Y Acad Sci. 1990;580(1):324-329.

32. Gailus-Durner V, Fuchs H, Becker L, et al. Introducing the German Mouse Clinic: open access platform for standardized phenotyping. Nat Methods. 2005;2(6):403-404. 
33. Lisse TS, Thiele F, Fuchs H, et al. ER stress-mediated apoptosis in a new mouse model of osteogenesis imperfecta. PLoS Genet. 2008;4(2):e7.

34. Forlino A, Porter FD, Lee EJ, Westphal H, Marini JC. Use of the Cre/lox recombination system to develop a non-lethal knock-in murine model for osteogenesis imperfecta with an $\alpha 1(\mathrm{I}) \mathrm{G} 349 \mathrm{C}$ substitution variability in phenotype in BrtlIV mice. J Biol Chem. 1999;274(53):37923-37931.

35. Uveges TE, Collin-Osdoby P, Cabral WA, et al. Cellular mechanism of decreased bone in Brtl mouse model of OI: imbalance of decreased osteoblast function and increased osteoclasts and their precursors. $J$ Bone Miner Res. 2008;23(12):1983-1994.

36. Boskey AL, Verdelis K, Spevak L, et al. Mineral and matrix changes in $\mathrm{Brtl} /+$ teeth provide insights into mineralization mechanisms. Biomed Res Int. 2013;2013:295812.

37. Forlino A, Cabral WA, Barnes AM, Marini JC. New perspectives on osteogenesis imperfecta. Nat Rev Endocrinol. 2011;7(9):540-557.

38. Sokolov BP, Mays PK, Khillan JS, Prockop DJ. Tissue- and development-specific expression in transgenic mice of a type I procollagen (COL1A1) minigene construct with $2.3 \mathrm{kB}$ of the promoter region and $2 \mathrm{kB}$ of the 3 '-flanking region: specificity is independent of the putative regulatory sequences in the first intron. Biochemistry. 1993;32(35):9242-9249.

39. Khillan JS, Olsen A, Kontusaari S, Sokolov B, Prockop D. Transgenic mice that express a mini-gene version of the human gene for type I procollagen (COL1A1) develop a phenotype resembling a lethal form of osteogenesis imperfecta. J Biol Chem. 1991;266(34):23373-23379.

40. Pereira R, Khillan JS, Helminen HJ, Hume EL, Prockop DJ. Transgenic mice expressing a partially deleted gene for type I procollagen (COL1A1): a breeding line with a phenotype of spontaneous fractures and decreased bone collagen and mineral. J Clin Invest. 1993;91(2):709-716.

41. Khillan JS, Li SW, Prockop DJ. Partial rescue of a lethal phenotype of fragile bones in transgenic mice with a chimeric antisense gene directed against a mutated collagen gene. Proc Natl Acad Sci U S A. 1994;91(14):6298-6302.

42. Campbell B, Wootton J, Krook L, DeMarco J, Minor R. Clinical signs and diagnosis of osteogenesis imperfecta in three dogs. J Am Vet Med Assoc. 1997;211(2):183-187.

43. Campbell BG, Wootton JA, MacLeod JN, Minor RR. Sequence of normal canine COL1A1 cDNA and identification of a heterozygous $\alpha 1$ (I) collagen Gly208AIa mutation in a severe case of canine osteogenesis imperfecta. Arch Biochem Biophys. 2000;384(1):37-46.

44. Campbell BG, Wootton JA, Macleod JN, Minor RR. Canine COL1A2 mutation resulting in C-terminal truncation of pro- $\alpha 2(\mathrm{I})$ and severe osteogenesis imperfecta. J Bone Miner Res. 2001;16(6):1147-1153.

45. Deak SB, Van Der Rest M, Prockop DJ. Altered helical structure of a homotrimer of $\alpha 1(\mathrm{I})$ chains synthesized by fibroblasts from a variant of osteogenesis imperfecta. Coll Relat Res. 1985;5(4):305-313.

46. Campbell BG, Wootton JA, MacLeod JN, Minor RR. Sequence of canine COL1A2 cDNA: nucleotide substitutions affecting the cyanogen bromide peptide map of the $\alpha 2$ (I) chain. Arch Biochem Biophys. 1998;357(1):67-75.

47. Van Eeden F, Granato M, Schach U, et al. Genetic analysis of fin formation in the zebrafish, Danio rerio. Development. 1996;123(1):255-262.

48. Asharani P, Keupp K, Semler O, et al. Attenuated BMP1 function compromises osteogenesis, leading to bone fragility in humans and zebrafish. Am J Hum Genet. 2012;90(4):661-674.

49. Durán I, Marí-Beffa M, Santamaría J, Becerra J, Santos-Ruiz L. Actinotrichia collagens and their role in fin formation. Dev Biol. 2011;354(1):160-172.

50. Fisher S, Jagadeeswaran P, Halpern ME. Radiographic analysis of zebrafish skeletal defects. Dev Biol. 2003;264(1):64-76.

51. Cabral WA, Chang W, Barnes AM, et al. Prolyl 3-hydroxylase 1 deficiency causes a recessive metabolic bone disorder resembling lethal/ severe osteogenesis imperfecta. Nat Genet. 2007;39(3):359-365.
52. Shapiro JR, Lietman C, Grover M, et al. Phenotypic variability of osteogenesis imperfecta type $\mathrm{V}$ caused by an IFITM5 mutation. $J$ Bone Miner Res. 2013;28(7):1523-1530.

53. Lietman CD, Marom R, Munivez E, et al. A transgenic mouse model of OI type V supports a neomorphic mechanism of the IFITM5 mutation. J Bone Miner Res. 2015;30(3):489-498.

54. Homan EP, Rauch F, Grafe I, et al. Mutations in SERPINF1 cause osteogenesis imperfecta type VI. J Bone Miner Res. 2011;26(12):2798-2803.

55. Barnes AM, Chang W, Morello R, et al. Deficiency of cartilageassociated protein in recessive lethal osteogenesis imperfecta. $N$ Engl $J$ Med. 2006;355(26):2757-2764.

56. Marini JC, Cabral WA, Barnes AM. Null mutations in LEPRE1 and CRTAP cause severe recessive osteogenesis imperfecta. Cell Tissue Res. 2010;339(1):59-70.

57. Doll JA, Stellmach VM, Bouck NP, et al. Pigment epithelium-derived factor regulates the vasculature and mass of the prostate and pancreas. Nat Med. 2003;9(6):774-780.

58. Bogan R, Riddle RC, Li Z, et al. A mouse model for human osteogenesis imperfecta type VI. J Bone Miner Res. 2013;28(7):1531-1536.

59. Morello R, Bertin TK, Chen Y, et al. CRTAP is required for prolyl 3-hydroxylation and mutations cause recessive osteogenesis imperfecta. Cell. 2006;127(2):291-304.

60. Fratzl-Zelman N, Morello R, Lee B, et al. CRTAP deficiency leads to abnormally high bone matrix mineralization in a murine model and in children with osteogenesis imperfecta type VII. Bone. 2010;46(3):820-826.

61. Baldridge D, Lennington J, Weis M, et al. Generalized connective tissue disease in Crtap-/- mouse. PloS One. 2010;5(5):e10560.

62. Vranka JA, Pokidysheva E, Hayashi L, et al. Prolyl 3-hydroxylase 1 null mice display abnormalities in fibrillar collagen-rich tissues such as tendons, skin, and bones. J Biol Chem . 2010;285(22):17253-17262.

63. Pokidysheva E, Tufa S, Bresee C, Brigande JV, Bächinger HP. Prolyl 3-hydroxylase-1 null mice exhibit hearing impairment and abnormal morphology of the middle ear bone joints. Matrix Biol. 2013;32(1):39-44.

64. van Dijk FS, Nesbitt IM, Zwikstra EH, et al. PPIB mutations cause severe osteogenesis imperfecta. Am J Hum Genet. 2009;85(4):521-527.

65. Barnes AM, Carter EM, Cabral WA, et al. Lack of cyclophilin B in osteogenesis imperfecta with normal collagen folding. $N$ Engl J Med. 2010;362(6):521-528.

66. Barnes AM, Cabral WA, Weis M, et al. Absence of FKBP10 in recessive type XI osteogenesis imperfecta leads to diminished collagen cross-linking and reduced collagen deposition in extracellular matrix. Hum Mutat. 2012;33(11):1589-1598.

67. Pyott SM, Schwarze U, Christiansen HE, et al. Mutations in PPIB (cyclophilin B) delay type I procollagen chain association and result in perinatal lethal to moderate osteogenesis imperfecta phenotypes. Hum Mol Genet. 2011;20(8):1595-1609.

68. Christiansen HE, Schwarze U, Pyott SM, et al. Homozygosity for a missense mutation in SERPINH1, which encodes the collagen chaperone protein HSP47, results in severe recessive osteogenesis imperfecta. Am J Hum Genet. 2010;86(3):389-398.

69. Nagata K. HSP47 as a collagen-specific molecular chaperone: function and expression in normal mouse development. Semin Cell Dev Biol. 2003;14(5):275-282.

70. Ishida Y, Kubota H, Yamamoto A, Kitamura A, Bächinger HP, Nagata $\mathrm{K}$. Type I collagen in Hsp47-null cells is aggregated in endoplasmic reticulum and deficient in $\mathrm{N}$-propeptide processing and fibrillogenesis. Mol Biol Cell. 2006;17(5):2346-2355.

71. Choi JW, Sutor SL, Lindquist L, et al. Severe osteogenesis imperfecta in cyclophilin B-deficient mice. PLoS Genet. 2009;5(12):e1000750.

72. Ishikawa Y, Wirz J, Vranka JA, Nagata K, Bächinger HP. Biochemical characterization of the prolyl 3-hydroxylase 1 cartilage-associated protein cyclophilin B complex. J Biol Chem. 2009;284(26):17641-17647.

73. Nagai N, Hosokawa M, Itohara S, et al. Embryonic lethality of molecular chaperone hsp47 knockout mice is associated with defects in collagen biosynthesis. J Cell Biol. 2000;150(6):1499-1506 
74. Tasab M, Batten MR, Bulleid NJ. Hsp47: a molecular chaperone that interacts with and stabilizes correctly-folded procollagen. EMBO J. 2000;19(10):2204-2211.

75. Seeliger F, Leeb T, Peters M, Brügmann M, Fehr M, HewickerTrautwein M. Osteogenesis imperfecta in two litters of dachshunds. Vet Pathol. 2003;40(5):530-539.

76. Drögemüller C, Becker D, Brunner A, et al. A missense mutation in the SERPINH1 gene in dachshunds with osteogenesis imperfecta. PLoS Genet. 2009;5(7):e1000579.

77. Alanay Y, Krakow D. Response to Shaheen et al. Am J Hum Genet. 2010;87(2):308.

78. Shaheen R, Al-Owain M, Sakati N, Alzayed ZS, Alkuraya FS. FKBP10 and Bruck syndrome: phenotypic heterogeneity or call for reclassification? Am J Hum Genet. 2010;87(2):306-307.

79. Alanay Y, Avaygan H, Camacho N, et al. Mutations in the gene encoding the RER protein FKBP65 cause autosomal-recessive osteogenesis imperfecta. Am J Hum Genet. 2010;86(4):551-559.

80. Lapunzina P, Aglan M, Temtamy S, et al. Identification of a frameshift mutation in osterix in a patient with recessive osteogenesis imperfecta. Am J Hum Genet. 2010;87(1):110-114.

81. Martínez-Glez V, Valencia M, Caparrós-Martín JA, et al. Identification of a mutation causing deficient BMP1/mTLD proteolytic activity in autosomal recessive osteogenesis imperfecta. Hum Mutat. 2012;33(2):343-350.

82. Shaheen R, Alazami AM, Alshammari MJ, et al. Study of autosomal recessive osteogenesis imperfecta in Arabia reveals a novel locus defined by TMEM38B mutation. J Med Genet. 2012;49(10):630-635.

83. Keupp K, Beleggia F, Kayserili H, et al. Mutations in WNT1 cause different forms of bone fragility. Am J Hum Genet. 2013;92(4):565-574.

84. Pyott SM, Tran TT, Leistritz DF, et al. WNT1 mutations in families affected by moderately severe and progressive recessive osteogenesis imperfecta. Am J Hum Genet. 2013;92(4):590-597.

85. Fahiminiya S, Majewski J, Mort J, Moffatt P, Glorieux FH, Rauch F. Mutations in WNT1 are a cause of osteogenesis imperfecta. J Med Genet. 2013;50(5):345-348.

86. Laine CM, Joeng KS, Campeau PM, et al. WNT1 mutations in early-onset osteoporosis and osteogenesis imperfecta. $N$ Engl J Med. 2013;368(19):1809-1816.

87. Symoens S, Malfait F, D'hondt S, et al. Deficiency for the ER-stress transducer OASIS causes severe recessive osteogenesis imperfecta in humans. Orphanet J Rare Dis. 2013;8:154.

88. Mendoza-Londono R, Fahiminiya S, Majewski J, et al. Recessive osteogenesis imperfecta caused by missense mutations in SPARC. Am J Hum Genet. 2015;96(6):979-985.

89. Lietman CD, Rajagopal A, Homan EP, et al. Connective tissue alterations in Fkbp10-/- mice. Hum Mol Genet. 2014;23(18):4822-4831.

90. Nakashima K, Zhou X, Kunkel G, et al. The novel zinc fingercontaining transcription factor osterix is required for osteoblast differentiation and bone formation. Cell. 2002;108(1):17-29.

91. Baek WY, Lee MA, Jung JW, et al. Positive regulation of adult bone formation by osteoblast-specific transcription factor osterix. $J$ Bone Miner Res. 2009;24(6):1055-1065.

92. Fisher S, Halpern ME. Patterning the zebrafish axial skeleton requires early chordin function. Nat Genet. 1999;23(4):442-446.

93. Lane PW. Swaying. Mouse News Lett. 1967;36:1.

94. Thomas KR, Capecchi MR. Targeted disruption of the murine int-1 proto-oncogene resulting in severe abnormalities in midbrain and cerebellar development. Nature. 1990;346(6287):847-850.

95. Thomas KR, Musci TS, Neumann PE, Capecchi MR. Swaying is a mutant allele of the proto-oncogene Wnt-1. Cell. 1991;67(5):969-976.

96. Joeng KS, Lee YC, Jiang MM, et al. The swaying mouse as a model of osteogenesis imperfecta caused by WNT1 mutations. Hum Mol Genet. 2014;23(15):4035-4042.

97. Bargman R, Posham R, Boskey A, DiCarlo E, Raggio C, Pleshko N. Comparable outcomes in fracture reduction and bone properties with RANKL inhibition and alendronate treatment in a mouse model of osteogenesis imperfecta. Osteoporos Int. 2012;23(3):1141-1150.
98. Evans K, Sheppard L, Rao S, Martin R, Oberbauer A. Pamidronate alters the growth plate in the oim mouse model for osteogenesis imperfecta. Int J Biomed Sci. 2009;5(4):345-352.

99. Uveges TE, Kozloff KM, Ty JM, et al. Alendronate treatment of the Brtl osteogenesis imperfecta mouse improves femoral geometry and load response before fracture but decreases predicted material properties and has detrimental effects on osteoblasts and bone formation. $J$ Bone Miner Res. 2009;24(5):849-859.

100. McCarthy EA, Raggio CL, Hossack MD, et al. Alendronate treatment for infants with osteogenesis imperfecta: demonstration of efficacy in a mouse model. Pediatr Res. 2002;52(5):660-670.

101. Rao S, Evans K, Oberbauer A, Martin R. Bisphosphonate treatment in the oim mouse model alters bone modeling during growth. J Biomech. 2008;41(16):3371-3376.

102. Camacho N, Carroll P, Raggio C. Fourier transform infrared imaging spectroscopy (FT-IRIS) of mineralization in bisphosphonate-treated oim/oim mice. Calcif Tissue Int. 2003;72(5):604-609.

103. Evans K, Lau S, Oberbauer A, Martin R. Alendronate affects long bone length and growth plate morphology in the oim mouse model for osteogenesis imperfecta. Bone. 2003;32(3):268-274.

104. Misof BM, Roschger P, Baldini T, et al. Differential effects of alendronate treatment on bone from growing osteogenesis imperfecta and wild-type mouse. Bone. 2005;36(1):150-158.

105. Quenzer J, Boachie-Adjei K, Boskey AL, Prockop D, Camacho NP, Raggio CL. Use of alendronate in long-term treatment of transgenic OI mice. Poster presented at: 50th Annual Meeting of the Orthopaedic Research Society; March 7-10, 2004; San Francisco, CA.

106. Boskey AL, Marino J, Spevak L, et al. Are changes in composition in response to treatment of a mouse model of osteogenesis imperfecta sex-dependent? Clin Orthop Relat Res. 2015;473(8):2587-1598.

107. Meganck J, Begun D, McElderry J, et al. Fracture healing with alendronate treatment in the Brtl/+ mouse model of osteogenesis imperfecta. Bone. 2013;56(1):204-212.

108. Wang HD, Boyce AM, Tsai JY, et al. Effects of denosumab treatment and discontinuation on human growth plates. J Clin Endocrinol Metab. 2014;99(3):891-897.

109. Semler O, Netzer C, Hoyer-Kuhn H, Becker J, Eysel P, Schoenau E. First use of the RANKL antibody denosumab in osteogenesis imperfecta type VI. J Musculoskelet Neuronal Interact. 2012;12(3):183-188.

110. Delos D, Yang X, Ricciardi BF, Myers ER, Bostrom MP, Camacho NP. The effects of RANKL inhibition on fracture healing and bone strength in a mouse model of osteogenesis imperfecta. J Orthop Res. 2008;26(2):153-164.

111. Bargman R, Huang A, Boskey AL, Raggio C, Pleshko N. RANKL inhibition improves bone properties in a mouse model of osteogenesis imperfecta. Connect Tissue Res. 2010;51(2):123-131.

112. Kostenuik PJ. Osteoprotegerin and RANKL regulate bone resorption, density, geometry and strength. Curr Opin Pharmacol. 2005;5(6):618-625.

113. Kostenuik PJ, Nguyen HQ, McCabe J, et al. Denosumab, a fully human monoclonal antibody to RANKL, inhibits bone resorption and increases BMD in knock-in mice that express chimeric (murine/ human) RANKL. J Bone Miner Res. 2009;24(2):182-195.

114. Anastasilakis AD, Toulis KA, Polyzos SA, Anastasilakis CD, Makras P. Long-term treatment of osteoporosis: safety and efficacy appraisal of denosumab. Ther Clin Risk Manag. 2012;8:295-306.

115. Neer RM, Arnaud CD, Zanchetta JR, et al. Effect of parathyroid hormone (1-34) on fractures and bone mineral density in postmenopausal women with osteoporosis. N Engl J Med. 2001;344(19): 1434-1441.

116. Jiang Y, Zhao J, Liao EY, Dai RC, Wu XP, Genant HK. Application of micro-CT assessment of 3-D bone microstructure in preclinical and clinical studies. J Bone Miner Metab. 2005;23(1):122-131.

117. Dempster DW, Cosman F, Kurland ES, et al. Effects of daily treatment with parathyroid hormone on bone microarchitecture and turnover in patients with osteoporosis: a paired biopsy study. J Bone Miner Res. 2001;16(10):1846-1853. 
118. Kurland ES, Cosman F, McMahon DJ, Rosen CJ, Lindsay R, Bilezikian JP. Parathyroid hormone as a therapy for idiopathic osteoporosis in men: effects on bone mineral density and bone markers. J Clin Endocrinol Metab. 2000;85(9):3069-3076.

119. Rodan GA, Martin TJ. Therapeutic approaches to bone diseases. Science. 2000;289(5484):1508-1514.

120. Black DM, Greenspan SL, Ensrud KE, et al. The effects of parathyroid hormone and alendronate alone or in combination in postmenopausal osteoporosis. N Engl J Med. 2003;349(13):1207-1215.

121. Mognetti B, Marino S, Barberis A, et al. Experimental stimulation of bone healing with teriparatide: histomorphometric and microhardness analysis in a mouse model of closed fracture. Calcif Tissue Int. 2011;89(2):163-171.

122. Kaback LA, Soung DY, Naik A, et al. Teriparatide (1-34 human PTH) regulation of osterix during fracture repair. $J$ Cell Biochem. 2008;105(1):219-226.

123. Dhillon RS, Schwarz EM. Teriparatide therapy as an adjuvant for tissue engineering and integration of biomaterials. J Mater Res. 2011;4(6):1117-1131.

124. Jacobson JA, Yanoso-Scholl L, Reynolds DG, et al. Teriparatide therapy and beta-tricalcium phosphate enhance scaffold reconstruction of mouse femoral defects. Tissue Eng Part A. 2010;17(3-4):389-398.

125. Reynolds DG, Takahata M, Lerner AL, O’Keefe RJ, Schwarz EM, Awad HA. Teriparatide therapy enhances devitalized femoral allograft osseointegration and biomechanics in a murine model. Bone. 2011;48(3):562-570.

126. Orwoll ES, Shapiro J, Veith S, et al. Evaluation of teriparatide treatment in adults with osteogenesis imperfecta. J Clin Invest. 2014;124(2):491-498.

127. Sinder BP, Eddy MM, Ominsky MS, Caird MS, Marini JC, Kozloff KM. Sclerostin antibody improves skeletal parameters in a Brtl/+ mouse model of osteogenesis imperfecta. J Bone Miner Res. 2013;28(1):73-80.

128. Horwitz EM, Andreef M, Frassoni F. Mesenchymal stromal cells. Curr Opin Hematol. 2006;13(6):419-425.

129. Li F, Wang X, Niyibizi C. Distribution of single-cell expanded marrow derived progenitors in a developing mouse model of osteogenesis imperfecta following systemic transplantation. Stem Cells. 2007;25(12):3183-3193.

130. Guillot PV, Abass O, Bassett JD, et al. Intrauterine transplantation of human fetal mesenchymal stem cells from first-trimester blood repairs bone and reduces fractures in osteogenesis imperfecta mice. Blood. 2008;111(3):1717-1725.

131. Campagnoli C, Roberts IA, Kumar S, Bennett PR, Bellantuono I, Fisk NM. Identification of mesenchymal stem/progenitor cells in human first-trimester fetal blood, liver, and bone marrow. Blood. 2001; 98(8):2396-2402.
132. Vanleene M, Saldanha Z, Cloyd KL, et al. Transplantation of human fetal blood stem cells in the osteogenesis imperfecta mouse leads to improvement in multiscale tissue properties. Blood. 2011;117(3):1053-1060.

133. Pereira RF, O'Hara MD, Laptev AV, et al. Marrow stromal cells as a source of progenitor cells for nonhematopoietic tissues in transgenic mice with a phenotype of osteogenesis imperfecta. Proc Natl Acad Sci U S A. 1998;95(3):1142-1147.

134. Li F, Wang X, Niyibizi C. Bone marrow stromal cells contribute to bone formation following infusion into femoral cavities of a mouse model of osteogenesis imperfecta. Bone. 2010;47(3):546-555.

135. Panaroni C, Gioia R, Lupi A, et al. In utero transplantation of adult bone marrow decreases perinatal lethality and rescues the bone phenotype in the knockin murine model for classical, dominant osteogenesis imperfecta. Blood. 2009;114(2):459-468.

136. Niyibizi C, Wang S, Mi Z, Robbins P. Gene therapy approaches for osteogenesis imperfecta. Gene Ther. 2004;11(4):408-416.

137. Schnieke A, Dziadek M, Bateman J, et al. Introduction of the human pro- $\alpha 1(\mathrm{I})$ collagen gene into pro- $\alpha 1(\mathrm{I})$-deficient Mov-13 mouse cells leads to formation of functional mouse-human hybrid type I collagen Proc Natl Acad Sci U S A. 1987;84(3):764-768.

138. Millington-Ward S, McMahon HP, Farrar GJ. Emerging therapeutic approaches for osteogenesis imperfecta. Trends Mol Med 2005;11(6):299-305

139. Weiss B, Davidkova G, Zhou LW. Antisense RNA gene therapy for studying and modulating biological processes. Cell Mol Life Sci. 1999;55(3):334-358.

140. Forlino A, Marini JC. Osteogenesis imperfecta: prospects for molecular therapeutics. Mol Genet Metab. 2000;71(1):225-232.

141. Evans C. Gene delivery to bone. Adv Drug Deliv Rev. 2012;64(12): 1331-1340.

142. Rose L, Uludağ H. Realizing the potential of gene-based molecular therapies in bone repair. J Bone Miner Res. 2013;28(11):2245-2262.

143. Osawa K, Okubo Y, Nakao K, Koyama N, Bessho K. Osteoinduction by repeat plasmid injection of human bone morphogenetic protein-2. J Gene Med. 2010;12(12):937-944.

144. Vanleene M, Shefelbine SJ. Therapeutic impact of low amplitude high frequency whole body vibrations on the osteogenesis imperfecta mouse bone. Bone. 2013;53(2):507-514.

145. Xie L, Rubin C, Judex S. Enhancement of the adolescent murine musculoskeletal system using low-level mechanical vibrations. J Appl Physiol (1985). 2008;104(4):1056-1062.

146. Malachanne E, Dureisseix D, Jourdan F. Numerical model of bone remodeling sensitive to loading frequency through a poroelastic behavior and internal fluid movements. J Mech Behav Biomed Mater. 2011;4(6):849-857.

147. Launey ME, Buehler MJ, Ritchie RO. On the mechanistic origins of toughness in bone. Annu Rev Mater Res. 2010;40:25-53.
Orthopedic Research and Reviews

\section{Publish your work in this journal}

Orthopedic Research and Reviews is an international, peer-reviewed, open access journal that focusing on the patho-physiology of the musculoskeletal system, trauma, surgery and other corrective interventions to restore mobility and function. Advances in new technologies, materials, techniques and pharmacological agents are particularly
Dovepress

welcome. The manuscript management system is completely online and includes a very quick and fair peer-review system, which is al easy to use. Visit http://www.dovepress.com/testimonials.php to read real quotes from published authors. 